\title{
The Influence of Executive Compensation and Executive Shares Ownership towards Corporate Tax Avoidance
}

\author{
Melisa Rahardja Tandiono \\ melisatan98@gmail.com \\ Accounting Study Program, Faculty of Business \\ President University, Cikarang, Indonesia \\ Setyarini Santosa \\ setyarinis@president.ac.id \\ Accounting Study Program, Faculty of Business \\ President University, Cikarang, Indonesia
}

\begin{abstract}
This study aims to examine the influence of executive compensation and executive shares ownership towards tax avoidance. By knowing the influence of executive compensation and executive shares ownership towards tax avoidance, it could be an input for better regulations relates to tax avoidance. This study used the annual report of property, real estate, and building construction company listed on Indonesia Stock Exchange during 2014-2018. This study uses purposive sampling to determine the samples. There are 14 companies used in this research, in total there are 70 annual reports as samples used in this research. The control variables used in this research are company performance proxied using return on asset and company size proxied using total asset. The method used in this research is multiple linear regression. This study found that executive compensation has significant influence with negative coefficient on tax avoidance and executive shares ownership does not influence tax avoidance.
\end{abstract}

Keywords: executive compensation; executive shares ownership; tax avoidance; cash effective tax rate

\begin{abstract}
Abstrak
Penelitian ini bertujuan untuk meneliti hubungan antara kompensasi eksekutif dan kepemilikan saham oleh eksekutif perusahaan terhadap penghindaran pajak. Diharapkan, hasil penelitian yang diperoleh akan dapat memberi masukan untuk peraturan-peraturan yang terkait dengan penghindaran pajak. Penelitian ini menggunakan laporan keuangan tahunan pada perusahaan property, real estat dan perusahaan konstruksi yang terdaftar di Pasar Modal Indonesia periode 2014-2018. Penelitian ini menggunakan purposive sampling untuk menentukan sampel. Ada 14 perusahaan yang digunakan dari total 70 laporan keuangan yang digunakan sebagai sampel dalam penelitian ini. Variabel kontrol yang digunakan adalah kinerja perusahaan yang diproksikan oleh return on assets dan ukuran perusahaan yang diproksikan dengan total asset. Metode yang digunakan dalam riset ini adalah regresi linier berganda. Hasil yang diperoleh dalam penelitian ini adalah bahwa kompensasi eksekutif memiliki pengaruh signifikan negative terhadap penghindaran pajak dan kepemilikan saham oleh eksekutif tidak memiliki pengaruh terhadap penghindaran pajak.
\end{abstract}

Kata kunci: kompensasi eksekutif; kepemilikan saham eksekutif; penghindaran pajak; casheffective tax rate 


\section{INTRODUCTION}

The state revenue comes from several sources that can be classified into three sources: tax revenue, non-tax revenue, and domestic grants. The main state revenue most likely depends on the income from tax. This could be proven by how the government always optimizing the income from tax. On the other hand, the company sees tax as the burden for the company. This makes many companies in various types of businesses try to do tax avoidance by reducing tax cost that must be paid to the state. Tax avoidance seen as one of the way to reduce tax burden which not against the law by making use the gaps that exist in the tax law to lower the company's tax burden. In PSAK 46 (Pernyataan Standar Akuntansi Keuangan 46), the profit of the company is classified into two: profit based on accounting (laba akuntansi) and profit based on tax (laba fiskal). The differences in the calculation of the profit based on accounting and based on tax would create some gaps that can be used to do tax avoidance. Companies believe that tax avoidance can provide economic benefits because it would increase the profit of the company. The matter about tax avoidance is very unique and yet complicated. In their effort to increase the profit resulted in a certain period, manager might try to increase their company's revenue and decreased their expenses, including doing the tax avoidance practice. This practice, of course, is not pleased the owner of the company too. It is inline with the agency theory. On the other hand, from the government perspective, tax avoidance is something that should be prevented because it could create lose in the sector of state revenue. This shows that between government and company have different interest relates to tax, where government would like to get more income in tax, meanwhile the company would like to reduce the tax that should be paid to the state. It is important for the government to seek the factor that could influence the tax avoidance in order to increase its tax revenues. For this explanation, this is important to make a study relates to tax and factors affecting tax avoidance becomes more apparent. This study would like to examine empirically the effect of executive compensation and executive shares ownership that affect the tax avoidance. By knowing the factor that could influence the tax avoidance, government is expected able to create regulations that could decrease the act of tax avoidance.

\section{LITERATURE REVIEW}

The purpose of the company is to maximize its value of the company that can be measured from the stock price of the company. However, managers may have other objectives that in conflict with the maximization of shareholder's wealth, as explained in the agency theory (Jensen \& Meckling, 1976). This could create a potential conflict of interest that occurs between the shareholder as the principal and the executive as the agent. In order to unify the different interest between the shareholders and the executives, the executives should have the feeling of owning the company by having the shares ownership within the company. If the executives have the sense of ownership, the executives might also satisfied when the company get an increasing profit or the disatisfied when company get decreasing profit.

As explained by the agency theory where the principal (shareholders) demand the agent (executives) to act based on principal's interest, shareholders might use executive compensation as a tool for executives to act in the interests of shareholders. Executive as the operational leader in the company would be willing to do any tax avoidance only if he would also get the benefit. Pora (2011) explained that there are several form of executive compensation: salary, incentive, allowances / benefit. Incentive would only be given to the employees if they could exceeding the required standard that has been determined. 
Allowance or benefit is compensation given in the form of services or facilities that could be enjoyed by the employees.

Hanafi and Harto (2014) found a positive influence between the executive compensation on tax avoidance. The compensation given to the executives is considered as the effective way to reduce the tax burden in order to increase the company performance. Armstrong et al, (2015) in their study found a positive influence between the executive compensation towards tax avoidance. By giving compensation, the shareholder expects the executive to increase the company's performance. One thing that the executive could do to increase the performance of the company is by lowering the tax burden that would lead to the act of tax avoidance. Ohnuma (2014) in his research also found that executive compensation is significantly related with tax avoidance activity. For this explanation, the hypothesis is stated as follow:

\section{$H_{1}$ : executives compensation has a positive influence on tax avoidance.}

Based to agency theory, the principal (the sharesholder) would ask the agent (managers / executives) to act based on the principal's desire. However, when the managers / executives have shares ownership of the company, they would also become the principal and having the same interest with other principal which is to increase their wealth. Ogbeide dan Obaretin (2018) in their research found that executive shares ownership as they mentioned as managerial ownership found that the ownership could make the managers / executives find some strategies to lower the operational expenses, including tax expenses. This research is also confirmed by Prasetyo and Pramuka (2018). Jamei (2017) in his research showing a significant influence between executive shares ownership which he mentioned as managerial ownership on tax avoidance. The company which has managerial ownership would do tax avoidance. Hanafi and Harto (2014) in their study found that executive shares ownership can have an influence on tax avoidance. Based on the explanation above, the hypothesis can be stated as follows:

$\mathrm{H}_{2}$ : shares ownership of executives has an influence on tax avoidance.

\section{RESEARCH METHOD}

\section{Operational Definitions of Variables}

The dependent variable in this study is tax avoidance. According to Jamei (2017), tax avoidance is the legal actions in order to reduce tax liabilities. The dependent variable of this study is tax avoidance. This tax avoidance variable is measured using the proxy of cash effective tax rate (CETR) following Titiek and Aryani (2016). CETR is the ratio of current tax expense to company profits before income tax. This CETR describe the amount of profit before tax sacrificed to pay the corporate tax burden. The range of CETR is between 0 until 1 (Titiek \& Aryani, 2016). The company which do the act of tax avoidance will have low CETR. The greater the amount of tax avoidance, the smaller the value of CETR and vice versa (Prayogo \& Darsono, 2015). The more the company pay the tax expense, it would result in the greater value of cash effective tax rate which means the tax avoidance is lower because the company pay the tax more. It also the same with the smaller the company pay the tax expense, the smaller the value of effective tax rate which means the tax avoidance is greater because the company pay less. 


$$
\text { Cash Effective Tax Rate }=\frac{\text { Total Current Tax Expense }}{\text { Earning Before Tax }}
$$

Executive compensation is the independent variable in this study. According to Yamina and Mohamed (2017), executive compensation policy is seen as the mechanism of action to resolve the conflict of interest that happened between the management and the shareholders in order to improve the business performance. This study follows Armstrong et al. (2015) which only tests the total compensation received by executives in a year. This research use the proxy of the total compensation that the directors / executives receive in a year. Executive shares ownership is the other independent variable in this study. According to Imanta (2011), executive shares ownership is the shares owned by the executive/ manager which means that the executives / managers also acts as the shareholder. Hanafi and Harto (2014) used the percentage of shares ownership held by the board of directors up to the end of the year to describe executive shares ownership. However, because of data limitation which some of the annual report provide mix shares ownership between commisioners and executives, this study uses the binnary data in order to find the influence of the existence of the executives shares ownership on tax avoidance. If the executives has shares ownership within the company, it would be presented as one, while if the executives has no shares ownership within the company, it would be presented as zero.The variable control in this research are company performance and company size. The company performance will be proxied using return on asset (net income divided by total assets). The company size will be proxied using the natural logarithm of total asset of the compay (Prayogo \& Darsono, 2015).

\section{Data and Sample Collection Techniques}

In order to get representative result, this study using quantitave method to collect the data. The population used in this study are the property, real estate, and building construction industry company listed in the Indonesia Stock Exchange (IDX) in the period 2014-2018. The sample was chosen with following criteria (Prayogo \& Darsono, 2015):

1. Registered as a public company consecutively during 2014-2018.

2. Disclosing the annual report in a year ended on 31st December. The current tax expense that is being used is the one-year period, annual report that should be used is the annual report that is ended on 31st December (one-year period).

3. Company which not suffering loss.

4. Company engaged in property, real estate, and building construction industry.

5. Annual financial reports that have data needed in research, which disclose the amount of curent tax expense, the amount of compensation received by executives, and information regarding the shares ownership within the company.

\section{Data Analysis Techniques}

This research using multiple regression method following Prayogo and Darsono (2015) with the research model as follows:

$$
\begin{array}{ll}
\qquad A V_{i}=\beta_{0}+ & \beta_{1} \operatorname{Comp}_{i}+\beta_{2} \mathrm{ExeOwn}_{i}+\beta_{3} \mathrm{ROA}_{i}+\beta_{4} \mathrm{Size}_{i}+\varepsilon_{i} \\
\text { Where: } & : \text { calculated using cash effective tax rate } \\
\text { TAV } & : \text { compensation received by executives in one year } \\
\text { Comp } & : \text { shares held by executive shareholders } \\
\text { ExeOwn } & : \text { return on asset } \\
\text { ROA } & : \text { natural logarithm of total asset } \\
\text { Size } & : \text { error } \\
\varepsilon &
\end{array}
$$




\section{RESULTS AND DISCUSSION}

This research uses the data taken from property, real estate, and building construction company listed in Indonesia Stock Exchange in five years period from 2014-2018. The samples taken in this research use purposive sampling in order to get representative result. After classifying the company based on the criterias, there are 14 companies being chosen and 70 annual reports would be taken as described in Table 1.

\section{Table 1. Sample Criteria}

\begin{tabular}{lc}
\hline Criteria & Number \\
\hline Property, real estate, and building construction companies registered in & 53 \\
Indonesia Stock Exchange consecutively from 2014-2018 & \\
Companies which not disclose the annual report in one year ended on & -1 \\
31st December & -11 \\
Companies that suffer loss & -10 \\
Companies which not disclose the amount of the current tax expenses & -2 \\
Companies which not provide information regarding executive & \\
compensation and shares ownership & -15 \\
Companies which the executive compensation is being mixed with the & \\
commissioner compensation & 14 \\
\hline Total Company used & 70 \\
\hline Total sample in 5 years & \\
\hline
\end{tabular}

From Table 2, the descriptive statistics on tax avoidance proxied using CETR (cash effective tax rate) shows that the mean of the CETR is 0.061430 with the standard deviation is 0.116914 . It reveals that the average company used in this research pay less tax expense to the state. The greater the CETR could be explained as the company pay more tax to the state. It could be said that the average samples used in this research has the aggresiveness in doing tax avoidance.

Table 2. Descriptive Statistic

\begin{tabular}{lrcrr}
\hline & CETR & COMPEN & ROA & SIZE \\
\hline Mean & 0.06143 & $2.41 \mathrm{E}+10$ & 0.053644 & $1.41 \mathrm{E}+13$ \\
Median & 0.0133 & $1.43 \mathrm{E}+10$ & 0.0405 & $1.13 \mathrm{E}+13$ \\
Maximum & 0.6679 & $1.64 \mathrm{E}+11$ & 0.1857 & $5.25 \mathrm{E}+13$ \\
Minimum & 0.0001 & $9.75 \mathrm{E}+08$ & 0.0017 & $4.02 \mathrm{E}+11$ \\
Std. Dev. & 0.116914 & $3.18 \mathrm{E}+10$ & 0.043287 & $1.09 \mathrm{E}+13$ \\
Observations & 70 & 70 & 70 & 70 \\
\hline
\end{tabular}

Source: Output Eviews 9

The analysis result using descriptive statistics on executive compensation showing that the average of the compensation given to the executives is Rp24,070,992,996 and the average of the ROA is 0.053644 . Descriptive statistics on company size proxied using total assets showing that the average is $14,120,769,629,836.97$. This amount showing that the average companies used in this research have such high company size. The higher the amount of the total assets the better because it means the company would be easier to get more investment from investor. 


\section{Classical Assumption Test}

Classical assumption test used in this research are nomality test, heteroskedasticity tets, multicollinearity test, and autocorrelation test. Each test will be explained below.

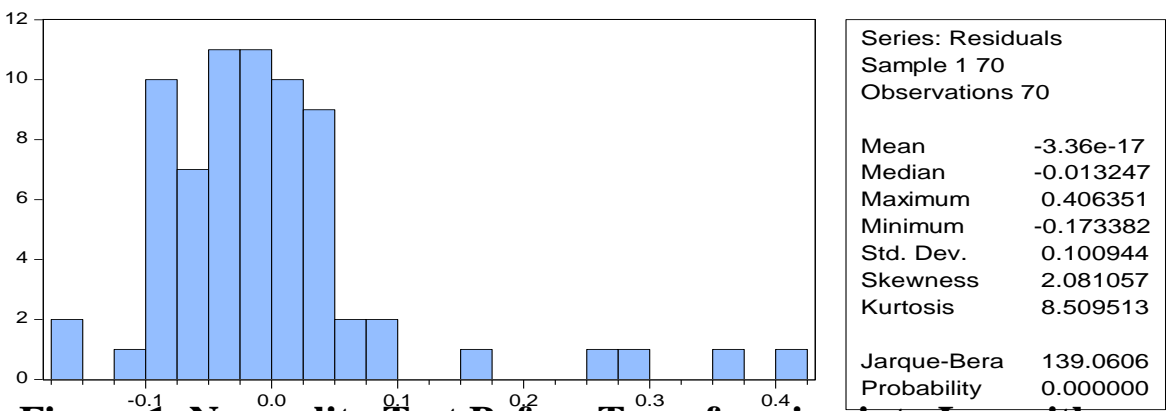

Figure 1. Normality Test Before Transforming into Logarithm Source: Output Eviews 9

Figure 1 shows the probability is 0 which lower than 0.05 , means that the data is not distributed normally. In order to normalize the data, it could use the transformation of logarithm (Jogiyanto, 2004).

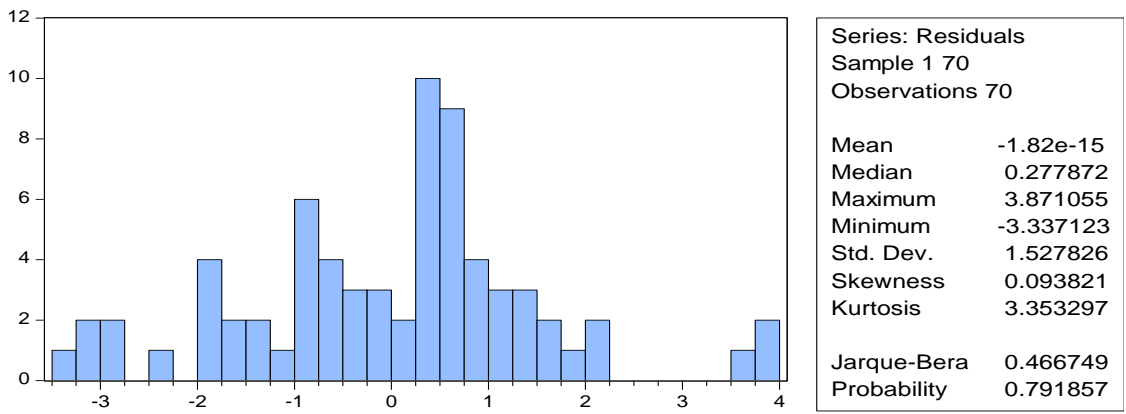

Figure 2. Normality Test After Transforming into Logarithm Source: Output Eviews 9

After transforming the dependent variable into logarithm, the data now becomes normal. It can be seen from the graph 4.2 , the statistic result showing the probability is 0.791857 which is greater than 0.05 . If the probability is greater than 0.05 means the data is distributed normally (Ghozali, 2013).

Table 3. Heteroskedasticity Harvey Test

\begin{tabular}{|c|c|c|c|}
\hline \multicolumn{4}{|c|}{ Heteroskedasticity Test: Harvey } \\
\hline F-statistic & 1.8209 & Prob. $F(4,65)$ & 0.1355 \\
\hline Obs*R-squared & 7.0535 & Prob. Chi-Square(4) & 0.1331 \\
\hline Scaled explained SS & 4.2826 & Prob. Chi-Square(4) & 0.3691 \\
\hline
\end{tabular}

According the result from Table 3, the probability of the Obs*R-squared is 0.1331 which greater than 0.05. When the first Prob. Chi-Square is greater than 0.05 means that there is no hesteroscedasticity occured in this research (Ghozali, 2013). 
Table 4. Multicollinearity Test

\begin{tabular}{ccrr}
\hline \multirow{2}{*}{ Variable } & \multicolumn{1}{l}{$\begin{array}{l}\text { Coefficient } \\
\text { Variance }\end{array}$} & \multicolumn{1}{l}{ Uncentered } & \multicolumn{2}{l}{ Centered } \\
& VIF & \multicolumn{2}{l}{ VIF } \\
\hline C & 28.69998 & 810.7674 & NA \\
COMPEN & $4.35 \mathrm{E}-23$ & 1.9359 & 1.223339 \\
EXEOWN & 0.181367 & $1.54 \mathrm{E}+00$ & 1.07595 \\
LOGROA & 0.046243 & $1.49 \mathrm{E}+01$ & 1.047427 \\
LOGSIZE & 0.033047 & 832.3775 & 1.233736 \\
\hline Source: Output Eviews 9 & &
\end{tabular}

As seen on Table 4, the uncentered VIF of the variable of compensation, executive ownership, return on assets, and company size are lower than 10 means there is no multicollinearity problem occured (Ghozali, 2013).

Table 5. Autocorrelation Test

\begin{tabular}{lrlr}
\hline Breusch-Godfrey Serial Correlation LM Test: & \\
\hline F-statistic & $1.74 \mathrm{E}+00$ & Prob. F(2,62) & $1.84 \mathrm{E}-01$ \\
Obs*R-squared & 3.6669 & Prob. Chi-Square(2) & 0.1599 \\
\hline Source: Output Eviews 9 & & &
\end{tabular}

Table 5 shows the autocorrelation test. The probability of the Obs*R-squared is 0.1599 which greater than 0.05 . When the first Prob. Chi-Square is greater than 0.05 means that there is no autocorrelation problem occured in this research (Ghozali, 2013)

Table 6. Coefficient Determination, t-Statistic and F-Statistic

\begin{tabular}{rcccc}
\hline \multicolumn{1}{c}{ Variable } & Coefficient & Std. Error & t-Statistic & Prob. \\
\hline C & -0.815698 & 5.357236 & -0.152261 & 0.8795 \\
COMPEN & $1.37 \mathrm{E}-11$ & $6.60 \mathrm{E}-12$ & 2.081477 & 0.0413 \\
EXEOWN & 0.664377 & 0.425872 & 1.560039 & 0.1236 \\
LOGROA & -1.077591 & 0.215042 & -5.011078 & 0 \\
LOGSIZE & -0.248196 & 0.18179 & -1.365293 & 0.1769 \\
\hline R-squared & 0.336209 & Mean dependent var & -4.184338 \\
Adjusted R-squared & 0.29536 & S.D. dependent var & 1.875246 \\
S.E. of regression & 1.574134 & Akaike info criterion & 3.814037 \\
Sum squared resid & 161.0633 & Schwarz criterion & 3.974643 \\
Log likelihood & -128.4913 & Hannan-Quinn criter. & 3.877832 \\
F-statistic & 8.230603 & Durbin-Watson stat & 2.039743 \\
Prob(F-statistic) & 0.00002 & & & \\
Dependent Variable: LOGCETR & & & & \\
Included observations: 70 & & & & \\
Source: Output Eviews 9 & & & &
\end{tabular}

Source: Output Eviews 9

Table 6 shows the amount of R-squared is 0.336209 or $33.6 \%$. It means that the variable used in this research which are executive compensation, executive shares ownerhsip, company performance, and company size could explain the tax avoidance. Adjusted Rsquared showing the value of 0.295360 , in percentage is $29.5 \%$. This amount shows that the 
independent variable in this research (executive compensation and executive shares ownership) could explain the tax avoidance for $29.5 \%$ while the rest $(100 \%-29.5 \%=$ $70.5 \%$ ) could be explained by other factors outside the independent variable.

\section{F-Statistic Test}

The probability of F-statistic in this study is 0.000020 which lower than 0.05 . When the probability of F-statistic is lower than 0.05 means that the executive compensation, executive shares ownerhsip, company performance, and company size influence tax avoidance simultaneously.

\section{t-statistic Test}

The amount of probability of t-statistic of compensation is 0.0413 which lower than 0.05 , it means that the variable of executive compensation influences the variable tax avoidance. The amount of probability of t-statistic of executive shares ownership is 0.1236 which greater than 0.05 , it means that the varible of executive shares ownership does not influence the variable tax avoidance. The amount of probability of t-statistic of ROA is 0.0000 which lower than 0.05 , it means that the variable of ROA influences the tax avoidance. The amount of probability of t-statistic of company size is 0.1769 which greater than 0.05 , it means that the variable of company size influences the tax avoidance. The variable of executive compensation (Compen) and executive shares ownership (EXEOWN) have positive correlation on cash effective tax rate while the variable of company performance (LOGROA) and company size (LOGSIZE) have negative correlation on cash effective tax rate.

\section{Discussion}

The executive compensation variable has influence towards tax avoidance with positive coefficient. By this result, $\mathrm{H}_{1}$ is supported because the executive compensation has influence on tax avoidance. However, it has positive coefficient on cash effective tax rate, which means it has negative coefficient on tax avoidance. When the compensation given to the executives is higher, it will lead to decreasing of the tax avoidance. It could be concluded that when the executives getting more compensation from the company, it would lead them to decrease the tax avoidance and paying more tax expenses. Apsari and Supdami (2018) in their research also found that executive compensation has negative significant influence towards tax avoidance. The more compensation the executives received, it would make them be more careful in making decisions for not doing aggresive tax avoidance. As the executives receive more compensation, they would have bigger responsibilities and they should be responsible for every decision they made. The act of tax avoidance that is done by the company would make the image of the company becomes bad. Executives as the decision makers would not want to do the act of tax avoidance that would make the image of the company becomes bad. The executive shares ownership variable has no influence towards tax avoidance that is proxied by CETR. This could be concluded that $\mathrm{H}_{2}$ is not supported. When the executives become the owner of the company, they would only interfere with any long-term decision making about how to keep the sustainability of the company. Any short-term decision making such as how to pay less tax expense would no longer become their responsibility. Prayogo and Darsono (2015) in their research also found no significant influence between executive shares ownership on tax avoidance.

\section{CONCLUSION}

Based on this research, can be concluded that executive compensation influence tax avoidance but in negative correlation. This research has different result with the research 
done by Armstrong et al, (2015) which showing that there is positive influence between executive compensation on tax avoidance. However, this researh has the same result with the research done by Apsari and Supdami (2018) which finding the negative significant influence between executive compensation on tax avoidance. Executive shares ownership does not influence tax avoidance. This research has different result with the research done by Jamei (2017) which showing significant negative influence between shares ownership as he called as managerial ownership on tax avoidance. However, this research has the same finding as the research done by Prayogo and Darsono (2015). The limitation in this research is the sample used in this research represents the company in higher performance, so that the result may not be resonated with the company with lower performance and could not represent the general situation in Indonesia. The other limitation that the writer faced during the process of this research was the data limitation. Some of the data of the compensation presented in the annual report does not separately present the amount given to the executives only, but also with the commisioners. This lead to the elimination of some observations and could not cover all the property, real estate, and building construction company in Indonesia. The next researchers could use the other sample from other industry in Indonesia in order to create more additional representation regarding the industry in Indonesia generally. Next researchers also could use another proxy as the measurement for tax avoidance.

\section{REFERENCES}

Apsari, A., \& Supadmi, N. L. (2018). Pengaruh kompensasi eksekutif, koneksi politik, dan capital intensity pada tax avoidance. E-Jurnal Akuntansi Universitas Udayana, 25(2), 1481-1505.

Armstrong, C., Blouin, J., Jagolinzer, A., \& Larcker, D. (2015). Corporate governance, incentives, and tax avoidance. Journal of Accounting and Economics, 60(1), 1-17.

Ghozali, I., \& Ratmono, D. (2013). Analisis multivariat dan ekonometrika teori, konsep, dan aplikasi dengan eviews 8. Semarang: Badan Penerbit Universitas Diponegoro Semarang.

Hanafi, U., \& Harto, P. (2014). Analisis pengaruh kompensasi eksekutif, kepemilikan saham eksekutif, dan preferensi risiko eksekutif terhadap penghindaran pajak perusahaan. Diponegoro Journal of Accounting, 3(2), 1-11.

Ikatan Akuntansi Indonesia (IAI). (2009). Pernyataan Standar Akuntansi Keuangan (PSAK) No 46: Akuntansi pajak penghasilan. Jakarta: Salemba Empat.

Imanta, D. (2011). Faktor-faktor yang mempengaruhi kepemilikan managerial. Jurnal Bisnis dan Akuntansi, 13(1), 67-80.

Jamei, R. (2017). Tax avoidance and corporate governance mechanisms: evidence from tehran stock exchange. International Journal of Economics and Financial Issues, 7(4), 638-644.

Jensen, M., \& Meckling, W. (1976). Theory of the firm: managerial behavior, agency costs, and ownership structure. Journal of Financial Economics 3, 3(4), 305-360.

Jogiyanto. (2004). Metode penelitian bisnis salah kaprah dan pengalaman-pengalaman. Yogyakarta: BPFE.

Ogbeide, S. O., \& Obaretin, O. (2018). Corporate governance mechanisms and tax aggressiveness of listed firms in Nigeria. Amity Journal of Corporate Governance, 3(1), $1-12$.

Ohnuma, H. (2014). Does executive compensation reflect equity risk incentives and corporate tax avoidance? a Japanese perspenctive. Corporate Ownership \& Control, 11(2), 60-71. 
Prasetyo, I., \& Pramuka, B. A. (2018). Pengaruh kepemilikan institusional, kepemilikan managerial, dan proporsi dewan komisaris independen terhadap tax avoidance. Jurnal Ekonomi, Bisnis, dan Akuntansi, 2(2).

Prayogo, K. H., \& Darsono. (2015). Faktor-faktor yang berpengaruh terhadap penghindaran pajak perusahaan. Diponegoro Journal of Accounting, 4(3), 1-12.

Titiek , A. P., \& Aryani, Y. (2016). Tren penghindaran pajak perusahaan manufaktur di Indonesia yang terdaftar di BEI tahun 2001-2014. Jurnal Akuntansi, 20(3), 375-388.

Yamina, A., \& Mohamed, B. (2017). The impact of firm performance on executive compensation in France. Mediterranean Journal of Social Sciences, 8(2), 63-69. 